\title{
PENDEKATAN BALANCED SCORECARD SEBAGAI ALTERNATIF PENILAIAN KINERJA SEKOLAH
}

\author{
Dian $^{1}$, Ega Rahmat Pauzi ${ }^{2}$ \\ Pascasarjana Universitas Islam Negeri (UIN) Sunan Gunung Djati Bandung; \\ Jalan Soekarno-Hatta-Gedebage Kota Bandung Jawa Barat 40292 \\ e-mail: 1dian@uinsgd.ac.id, ${ }^{2}$ egaibnuubaidillah@gmail.com
}

\begin{abstract}
This study aims to explore the concept of school performance appraisal using the balanced scorecard. Here, the authors attempt to describe the concept of a balanced scorecard that is applicable for the assessment of school performance. The methodology used is qualitative method that relies on a literature review of the literature and research journals. It was found that the concept of the balanced scorecard is a strategic alternative evaluation tool organization that focuses on financial performance. Balanced scorcard base its scoring on four aspects, namely financial, customer, internal business processes, and growth and development. Given the balanced scorecard approach emerged and developed within a business organization it is necessary to attempt modification before being used for the assessment of school performance. Therefore, in the context of the fourth school into a balanced scorecard assessment factors and infrastructure funds, students, curricular activities, and teachers and education personnel. It is expected that this study can contribute conceptually applicable to researchers and the public who will evaluate the performance of schools using a balanced scorecard approach. Keywords: Balanced Scorecard, School Performance Assessment
\end{abstract}

\begin{abstract}
Abstrak
Penelitian ini bertujuan untuk menelusuri konsep penilaian kinerja sekolah yang menggunakan balanced scorecard. Disini penulis berupaya menguraikan konsep balanced scorecard yang aplikatif bagi penilaian kinerja sekolah. Metodologi penelitian yang digunakan yaitu metode kualitatif yang mengandalkan pada kajian pustaka dari berbagai literatur dan jurnal penelitian. Berdasarkan penelitian ditemukan bahwa konsep balanced scorecard merupakan alternatif alat evaluasi strategi organisasi yang selama ini terpusat pada kinerja keuangan. Balanced scorcard mendasarkan penilaian pada empat aspek yaitu keuangan, pelanggan, proses bisnis internal, dan pertumbuhan dan perkembangan. Mengingat pendekatan balanced scorecard muncul dan berkembang di lingkungan organisasi bisnis maka perlu upaya modifikasi sebelum digunakan untuk penilaian kinerja sekolah. Oleh karena itu dalam konteks sekolah keempat faktor penilaian balanced scorecard menjadi dana dan sarana prasarana, siswa, kegiatan kurikuler, dan pendidik dan tenaga kependidikan. Diharapkan penelitian ini dapat memberikan sumbangan konseptual yang aplikatif bagi peneliti maupun masyarakat yang akan melakukan evaluasi kinerja sekolah menggunakan pendekatan balanced scorecard.
\end{abstract}

Kata Kunci: Balanced Scorecard, Penilaian Kinerja Sekolah 


\section{A. PENDAHULUAN}

Dalam organisasi cara untuk mengetahui tercapai tidaknya suatu tujuan dapat diungkap melalui pengukuran kinerja organisasi. Kinerja organisasi merupakan perilaku anggota organisasi yang dapat mendorong semua anggota organisasi untuk mencapai tujuan organisasi yang telah ditentukan. Kinerja organisasi ini bersifat dinamis.

Terdapat banyak model pengukuran kinerja yang ditawarkan para peneliti. Biasanya para pengelola lebih memilih model pengukuran kinerja berbasis keuangan. Akibatnya, banyak faktor lain yang tidak tersentuh. Padahal kinerja organisasi lebih kompleks apalagi organisasi besar.

Maka munculah teori balanced scorecard yang ditawarkan oleh Kaplan dan Norton. Pendekatan ini begitu populer di kalangan industri. Kelebihannya adalah cakupan penilaiannya dipandang lebih komprehensif. Selain itu, keluasan perspektif yang ditawarkan pendekatan ini memungkinkan para pengelola mendapatkan informasi yang lebih objektif (ArifRamdhani, 2011:102).Selain itu balanced scorecard tidak hanya membantu para pengelola mengevaluasi kinerja organisasinya melainkan bisa menjadi sistem manajemen strategi untuk mengatur strategi jangka panjang (Kaplan dan Norton, 1996:2).

\section{B. TUJUAN PENELITIAN}

Tujuan penelitianiniadalah menggali literatur mengenai teknik penilaian balanced scorecard yang dapat diterapkan dalam konteks lembaga pendidikan. Penelaahan literasi ini diharapkan dapat membuka ruang bagi para pengelola sekolah untuk bisa mengaplikasikan teknik penilaian ini di lembaganya masingmasing.

\section{METODE PENELITIAN}

Penelitian ini menggunakan pendekatan studi literatur. Sumber data berasal dari beberapa buku dan jurnal penelitian. Menurut Zed (2014) penelusuran pustaka berupaya memanfaatkan sumber-sumber perpustakaan untuk mendapatkan data penelitian.

\section{HASIL PENELITIAN}

\section{Balanced Scorecard}

Balanced Scorecard adalah alat evaluasi strategi yang penting. Ini adalah sebuah proses yang memungkinkan perusahaan untuk mengevaluasi strategi berdasarkan empat strategi: kinerja keuangan, pengetahuan pelanggan, proses bisnis internal, dan pembelajaran serta pertumbuhan. Menurut Kaplan dan Nortonbalanced Scorecard memungkinkan perusahaan memeriksa data keuangan diiringi melihat laju perkembangan perusahaan dengan tujuan meningkatkan kapabilitas dan menyiapkan aset yang akan dibutuhkan di masa depan (Kaplan dan Norton, 1996:2). Berikut penjelasan keempat perspektif tersebut (IrfanFahmi, 2017:233).

\section{a. Perspektiffinansial}

Balanced scorecard berawal dari pengukuran kinerja di sektor bisnis. Disini maksud perspektif finansial adalah financial sustainability. Perspektif ini digunakan oleh shareholder dalam rangka penilaian kinerja organisasi.

Dalam perspektif finansial, terdapat tiga aspek dari strategiyang dilakukan suatu perusahaan; (1) pertumbuhan pendapatan dan kombinasipendapatan yang dimiliki suatu organisasi bisnis, (2) penurunan biaya dan peningkatanproduktivitas, (3) penggunaan aset yang optimal dan strategi investasi (Ciptani, 2000:25).

\section{b. Perspektif customer}

Perspektif customer adalah perspektif yang berorientasi pada pelanggan. Dasar pemikirannya adalah para pelanggan tersebut berperan sebagai pemakai produk atau jasa yang dihasilkan organisasi.

Dalam perspektif ini, pengukuran dilakukan dengan lima aspek utama yaitu (Kaplan dan Norton, 1996: 67):

1) Pengukuran pangsa pasar

Pengukuran terhadap besarnya pangsa pasar perusahaan mencerminkan proporsi bisnis dalam satu area bisnis tertentu yang diungkapkan dalam bentuk uang, jumlah customer, atau unit volume yang terjual atas setiap unit produk yang terjual.

\section{2) Customer retention}

Pengukuran dapat dilakukan dengan mengetahui besarnya prosentase pertumbuhan bisnis dengan jumlah customer yang saat ini dimiliki oleh perusahaan.

\section{3) Customer acquisition}

Pengukuran dapat dilakukan melalui prosentase jumlah penambahan customer baru dan perbandingan total penjualan dengan jumlah customer baru yang ada.

4) Customer satisfaction

Pengukuran terhadap tingkat kepuasan pelanggan ini dapat dilakukan dengan berbagai macam teknik diantaranya adalah : survei melalui surat (pos), interview melalui telepon, atau personal interview.

5) Customer profitability

Pengukuran terhadap customer profitability dapat dilakukan dengan menggunakan teknik Activity Based-Costing (ABC). 
c. Perspektif internal business process

Perspektif internal business processadalah serangkaian aktivitas yang ada dalam organisasi untuk menciptakan produk atau jasa dalam rangka memenuhi harapan pelanggan. Perspektif ini menjelaskan proses bisnis yang dikelola untuk memberikan layanan dan nilainilai kepada stakeholder dan customer.

Berdasarkan perspektif ini, perusahaan berfokus pada tiga proses bisnis utamayaitu proses inovasi, proses operasi, proses pasca penjualan. Berikut penjelasan dari masingmasing proses tersebut (Ciptani, 2000:27-28).

d. Perspektif learning dan growth

Perspektif learning dan growth adalah perspektif yang menggambarkan kemampuan organisasi untuk melakukan perbaikan dan perubahan dengan memanfaatkan sumber daya internal organisasi. Kesinambungan suatu organisasi dalam jangka panjang sangat bergantung pada perspektif ini.

\section{Penerapan Balanced Scorecard dalam Penilaian Kinerja Sekolah}

Dalam konteks institusi pendidikan atau sekolah, pelanggan adalah yang menikmati pelayanan pendidikan. Kamisa dalam Nurkholis menjelaskan secara rinci pelanggan pendidikan terdiri dari dua macam, yaitu pelangggan internal dan pelanggan eksternal (Nurkholis, 2003:110).

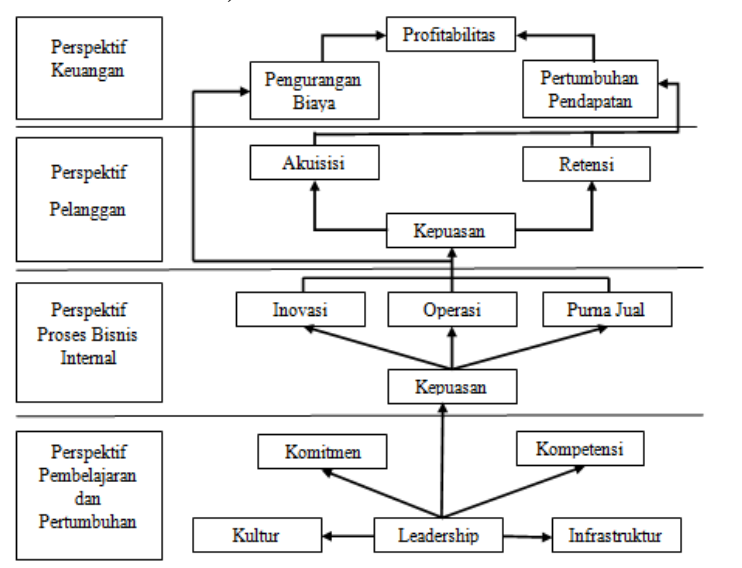

Gambar 1. Translasi Visi dan Strategi dalam Balanced Scorecard. Sumber: Kaplan dan Norton (2000) dalam Arif Ramdhani (2011:103).

a. Pelanggan internal (kepala sekolah, guru dan karyawan sekolah)

Pendidikan berkualitas jika memperoleh timbale balik baik dari segi materi maupun non materi. Materi yang bias diperoleh pegawai seperti gaji, bonus prestasi kerja, pakaian, dan lain-lain. Sedangkan non materi pelanggan internal memiliki kesempatan mengembangkan potensi dirinya, komunikasi yang baik, dan memiliki rekan kerja yang dapat dipercaya.

b. Pelanggan Eksternal:

1) Eksternal Primer (Para Siswa); menjadi peserta didik yang memiliki pengetahuan luas, berkarakter, proaktif dalam berbagai permasalahan, terampil, dan lain-lain.

2) Eksternal Sekunder (orang tua,para pemimpin pemerintahan, dan perusahaan/dunia usaha dan industri); para lulusan memenuhi ekspektasi orang tua, berguna bagi bangsa dan negara, ikut sertadalam memajukan negeri, dan berperan dalam pengembangan dunia usahadan dunia industri.

c) Eksternal tersier (pasar kerja dan masyarakat luas); para lulusan dapat berkontribusi ditengah-tengah masyarakat dan memiliki keterampilan yang dibutuhkan pasar kerja.

Menurut Mahmudi kinerja keuangan pada sekolah berkaitan dengan pemanfaatan anggaran secara maksimal. Masyarakat sebagai pembayar pajak sekaligus stakeholder pendidikan mengharapkan uang yang dibayarkan digunakan secaraekonomis,efisien, danefektif (value for money) serta memenuhi prinsip akuntabilitas publik (Mahmudi, 2010:83).

Perspektif bisnis internal sekolah adalah membangun keunggulan organisasi melalui perbaikan proses internal sekolah secara berkelanjutan. Pengelola sekolah harus memiliki satu fokus yang menjadi keunggulan tersendiri terutama bila dibandingkan dengan pesaing. Konsep BSC menawarkantigahal yangharus dijalankan sekolah yaitu innovation process, operation process, dan post sale process.

Perspektif selanjutnya adalah pembelajaran dan pertumbuhan. Perspektif ini menekankan pada upaya menjaga dan membangun keunggulan organisasi dalam jangka panjang. Prinsip penting dalam perspektif pembelajaran dan pertumbuhan adalah kemampuan guru dan karyawan, kemampuan sistem informasi, dan tingkat motivasi/pemberdayaan. Faktor lain dari perspektif pembelajaran dan pertumbuhan adalah implementasi teknologi dalam organisasi (JokoPramono, 2014:1343).

Achmad Sanusi mengungkapkan modifikasi lain empat faktor balanced scorecard pada pengukuran kinerja sekolah. Dengan berpedoman pada Kaplan dan Norton, konsep manajemen strategik dalam dunia pendidikan bisa dioperasionalisasikan dan diuraikan secara praktis dengan bantuan 
balanced scorecard. Dalam balanced scorecard, para pengelola memfokuskan diri pada visi, misi, dan strategi melalui empat perspektif tersebut.

Achmad Sanusi mengilustrasikan empat perspektif balanced scorecard sebagai mana berikut (Achmad Sanusi, 2014:38).

a. Perspektif kurikulum yang melihat isi dan proses pembelajaran serta evaluasi hasil belajar dan tujuan pembelajarannya.

b. Perspektif siswa yang melihat kebutuhan belajar, cara pembelajarannya, dan karakteristik individualnya yang dilayani oleh organisasi pendidikan.

c. Perspektif pendidik dan tenaga kependidikan yang melihat tugasnya, keahliannya, kesediaan belajarnya, hubungan kerjasama, dan teamwork dalam konteks system organisasinya.

d. Perspektif dana, sarana dan prasarana yang melihat anggaran, penerimaan atau pendapatan, dan pengeluaran atau biaya (modal dan operasional) serta pembukuannya dan sarana-prasarana yang diperlukan untuk menyelenggarakan pendidikan.

Sebagaimana telah disebutkan sebelumnya, penerapan empat perspektif tersebut harus seimbang. Oleh karena itu, pengendalian perspektif balanced scorecard membutuhkan kepemimpinan yang mumpuni. Setidaknya seorang pemimpin tersebut harus memiliki keterampilan menjalankan organisasi, kemampuan manajemen strategik atau mutu, kecakapan mengendalikan teamwork dengan komunikasi formal dan informal, dan kemampuan memahami dan menghayati visi, misi, strategi lembaga pendidikan tersebut secara simultan dan berkelanjutan.

Dalam konteks pendidikan, keempat perspektif tersebut divisualisasikan seperti berikut:

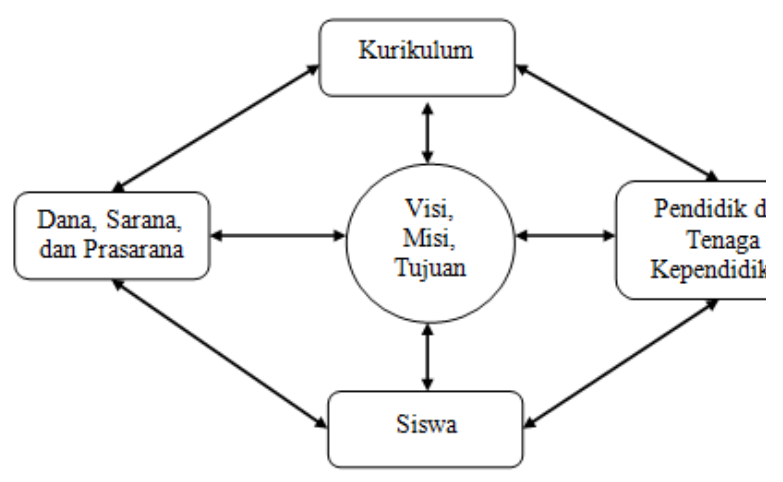

Gambar 5. Balanced Scorecard dalam konteks Pendidikan

Sumber: Achmad Sanusi (2014)

Manajemen strategi berbasis balanced scorecard mensyaratkan adanya program teknologi informasi organisasi yang efektif. Untuk merealisasikan hal tersebut, disyaratkan kinerja beberapa faktor yang terintegrasi. Faktor tersebut yaitu software, hardware, infrastruktur telekomunikasi yang disediakan provider, sumber daya manusia dengan keahlian dan pengalaman, organisasi intelektual, dan manajemen (AchmadSanusi, 2014:46).

Tabel 1. Perspektif Balanced Scorecard pada Organisasi Bisnis dan Pendidikan

\begin{tabular}{|c|c|}
\hline Kaplan dan Norton: & Achmad $\quad$ Sanusi: \\
\hline $\begin{array}{ll}\text { Empat } & \text { Perspektif } \\
\text { dalam } & \text { Organisasi } \\
\text { Bisnis } & \end{array}$ & $\begin{array}{l}\text { Balanced Scoercard pada } \\
\text { Organisasi Pendidikan }\end{array}$ \\
\hline Finance & Dana dan Sarana-Prasarana \\
\hline Customer & Siswa \\
\hline $\begin{array}{l}\text { Internal Business } \\
\text { Process }\end{array}$ & Kegiatan Kurikuler \\
\hline $\begin{array}{l}\text { Learning } \\
\text { Growth }\end{array}$ & Pendidik dan Tenaga Kependidikan \\
\hline
\end{tabular}

\section{E. SIMPULAN}

Pendekatan balanced scorecard bisa digunakan diluar organisasi bisnis. Dunia pendidikan bisa mengadopsi pendekatan tersebut. Tentu hal itu harus diikuti dengan penyesuaian dan kajian terlebih dahulu. Keempat perspektif tersebut disesuaikan dengan realitas pendidikan. Perspektif finansial berupa keuangan sekolah, sarana dan prasarana, perspektif pelanggan terbagi dua yaitu pelanggan internal (pengelola sekolah) dan pelanggan eksternal (siswa, orang tua siswa), perspektif proses bisnis internal yang menekankan pada faktor keunggulan lembaga, dan perspektif pembelajaran dan pertumbuhan berupa penyediaan sistem informasi dan pemberdayaan pendidik dan tenaga kependidikan.

\section{DAFTAR PUSTAKA}

Ciptani, Monika Kussetya, 2000, Balanced Scorecard sebagai Pengukuran Kinerja Masa Depan: Suatu Pengantar, Jurnal Akuntansi \& Keuangan, No. 1, Vol. 2, 21-35, :https: //media.neliti.com/media/publications/ 73587-ID-balanced-scorecard-sebagaipengukuran- 
ki.pdf\&ved=2ahUKEwjXyvz38evlAh

Vr6XMBHX8kDV8QFjAAegQIBRA

B\&usg=AOvVaw3eGolXoxkaYKaB5 MP5pBVS

Fahmi, Irfan, 2017, Manajemen Strategis Teori dan Aplikasi, Alfabeta, Bandung.

Kaplan, Robert S., dan Norton,David P., 1996,Translating Strategy Into Action: The Balanced Scorecard, the President and Fellows of Harvard College, Massachusetts.

Mahmudi, 2010, Manajemen Kinerja Sektor Publik, STIE YKPN, Yogyakarta.

Nurkholis, 2003, Manajemen Berbasis Sekolah, Teori, Model, dan Aplikasi, PT.Gramedia Widiasarana Indonesia, Jakarta.

Pramono,Joko, 2014, Analisis Pengukuran Kinerja SMK Negeri 6 Surakarta Dengan Pendekatan Balanced Scorecard, Gema, No. 48, Vol. 26, 1335-1355,

:https://www.neliti.com/publications/6 1569/analisis-pengukuran-kinerja-smknegeri-6-surakarta-dengan-pendekatanbalanced-sc

Ramdhani, Arif, 2011, Penilaian Kinerja, PT Sarana Panca Karya Nusa, Bandung.

Sanusi,Achmad,2014, Pembaharuan Strategi Pendidikan, Penerbit Nuansa Cendekia, Bandung.

Zed, M, 2014, Metode Penelitian Kepustakaan, Yayasan Obor Indonesia, Jakarta. 